\title{
Morphometric Assessment of Meandering River in Arid Region Using Improvement Model (Case Study: Maroon River)
}

\author{
Mehran Maghsoudi*, Seyyed Mohammad Zamanzadeh, Mojtaba Yamani, \\ Abdolhossein Hajizadeh \\ Geomorphology, Tehran University, University of Tehran, Iran \\ Email: ^maghsoud@ut.ac.ir, zamanzadeh@ut.ac.ir, myamani@ut.ac.ir, hajizadeh6331@gmail.com
}

How to cite this paper: Maghsoudi, M., Zamanzadeh, S.M., Yamani, M. and Hajizadeh, A. (2017) Morphometric Assessment of Meandering River in Arid Region Using Improvement Model (Case Study: Maroon River). Journal of Water Resource and Protection, 9, 358-377.

https://doi.org/10.4236/jwarp.2017.94024

Received: July 25, 2016

Accepted: March 19, 2017

Published: March 22, 2017

Copyright (c) 2017 by authors and Scientific Research Publishing Inc. This work is licensed under the Creative Commons Attribution International License (CC BY 4.0).

http://creativecommons.org/licenses/by/4.0/

\begin{abstract}
To understand the natural environments of drylands, deserts, arid and semiarid regions of the earth is to understand the processes and forms of their rivers. One of the river studies and fluvial processes are morphometry analyses. The channel forms in an alluvial plain reflecting the movement of water and the particle size of the load flowing down the channel. The dynamics of channel change has led to conflict with human resource development. Three basic channel patterns are detected in the region. They are braided, meandering and straight. In this research for assessment of meandering Maroon River, we used DEM (Digital Elevation System), Topography maps, Arc GIS software, Google earth, field work and library studies and mathematic formula. The two general indices for analyzing meandering patterns are 1) sinuosity coefficient 2) central angle. In this paper, the authors were used these factors and improved them. One of the results is creation of direction index and the second result is the Maroon River which has a type of sinuosity in any reach.
\end{abstract}

\section{Keywords}

Iran, Maroon River, Meandering Rivers, Sinuosity Coefficient, Central Angle, Direction Index, Behbahan Plain

\section{Introduction}

Geomorphology as a discipline in Earth Science has its roots from Geology, Hydraulic Engineering and Physics. This is different from other natural sciences in which its focus is on the study of the processes of production, movement and storage of sediment within the landscape and on the characterization of the features 
these processes produce. In its widest definition, Geomorphology encompasses the study of glacial, coastal, slope, wind and fluvial processes of sediment movement across the surface of the Earth [1]. The geomorphological variety in landforms and underlying processes makes natural rivers diverse and dynamic ecosystems. The frequently changing and diverse patterns of landforms and riparian wetlands provide a large diversity of habitats and land-water boundaries and consequently host a great abundance of wildlife. As a result, rivers are particularly important corridors along which many organisms may disperse through the landscape [2]. Arid zones cover $30 \%$ or more of the global land surface and support an ever-growing human population [3]. Rivers in these zones (called arid zone rivers or dry land rivers) often play a central role in landscape change and exert a strong influence on human use of the marginal environments [4]. Therefore, the processes, forms and change of these rivers are increasingly a focus of scientific and applied interests. To understand the natural environments of drylands, deserts, arid and semi-arid regions of the earth is to understand the processes and forms of their rivers [5]. Because rivers are systems that integrate and reflect the complete environment in which they form, as environments change so do the river systems and they support [6]; river sedimentation and morphological processes are among the most complex and least understood phenomena in nature. Due to the fact that they intimately have effects on our living conditions, scientists and engineers have been looking for better tools to improve our understanding and enhance the quality of our lives ever since the beginning of human civilization. In early times, the research methodologies were primarily based on field observation and physical modeling [7]. Rivers are found in many different climatic zones, ranging from humid to arid, and from equatorial to arctic. Some of the larger rivers even flow across different climatic zones, originating in a humid area before flowing through an arid region [8].

Many dryland rivers have already been strongly influenced by, or under threat from, flow regulation schemes or other human activities such as agriculture, mining, or urbanization, with these developments often having detrimental effects on channel morphology and associated ecology [9]. Rivers are the arteries of the landscape. The dynamics of channel change have led to conflict with human resource development [1]. Rivers have important role in human Settlements. Locations of human settlements in prehistoric and historic periods were the results of interaction between human adaptation and the environment like rivers, mountains, plain and etc.

Therefore, rivers study not only illuminates the morphometry of rivers, it also can generate human information like archaeology, geoarchaeology and etc. Morphological processes are among the most complex and least understood phenomena in nature. River morphology has been a subject of great challenge to scientists and engineers who recognize that any effort with regard to river engineering must be based on a proper understanding of the morphological features involved and the responses to the imposed changes. River morphology is often presented from the geomorphic viewpoint [10]. Morphometry is an essential 
means in geomorphic analysis of an area [11]. Morphometry is defined as the measurement and mathematical analysis of the configuration of the earth's surface and of the shape and dimension of its landforms [12]. Morphometric methods, though simple, have been applied for the analysis of area-height relationships, determination of erosion surfaces, slopes, relative relief and terrain characteristics, river basin evaluation, and watershed prioritization for soil and water conservation activities in river basins [13]. The morphometry of the river basins relates to the hydrological and geomorphic response of processes like runoff, soil erosion, floods and droughts, river sedimentation, changing river flows and branching habit of the streams, flow characteristics of the drainage lines, and on the performance and sustainability of the associated dams and reservoirs if available within the basin [14] [15]. Fluvial geomorphology is the study of the interactions between river channel forms and processes at a range of space and time scales. The influence of past events is also significant in explaining the present form of river channels. Rivers are found in many different environments and show an amazing diversity of form [8]. The channel forms in an alluvial plain reflect the movement of water and the particle size of the load flowing down the channel. The greater the water volume in channel, the wider and deeper is the channel [16]. Three basic channel patterns are detected in alluvial plains. They are braided, meandering and straight. River morphology is explained by channel patterns and channel forms and is decided by such factors as discharge, water surface slope, water velocity, depth and width of the channel, and river bed materials, etc. [16]. And variations in channel type are largely a function of channel gradient, valley confinement, and particle size [17]. Fluvial morphology is conditioned by three basic elements: flow regime, sediment yield and valley characteristics [18].

\subsection{The Characteristics of These Types of Channels Are}

\subsubsection{Straight Channels (Single Thread)}

1) Constrained; mobile alternate bars; gravel environments.

2) Rare; unstable.

3) Thalweg-deepest part.

\subsubsection{Braided Channels}

1) Multiple-thread channels, dominated by mid channel bars, commonly gravel.

2) Large width-to-depth rations, very unstable with frequent lateral shifts.

3) Often totally re-arranged by large floods, no levees, non-cohesive banks.

Braided channels are characterized by multiple channel threads that split and rejoin or interconnect with other braided channels contained within a wider braid plain [17] or Braided Rivers consist of numerous alluvial channels that divide and rejoin around bars and islands, forming an intertwining structure that resembles a braid. They prevail in mountainous and glacial regions, and are highly dynamic systems characterized by intensive erosion, sediment transport and deposition, and frequent channel shifting. The alluvial deposits of braided rivers are important reservoirs of water, oil, gas, coal, sand, gravel and heavy minerals 
[19].

\subsubsection{Meandering}

1) Single thread channel, sinuous plan form, point bars in each bend.

2) Moderate width-to-depth rations, cohesive banks, associated with levees, finegrained floodplain sediments [20].

Meandering channels are sinuous single-thread channels that are typically found on low slopes and in fine-textured floodplain soils, i.e., silt and clay [21].

Meandering channels develop worldwide on rivers of all sizes, reflecting the propensity for a sinuous plan form to develop on rivers where the channel is free to migrate across an unconfined floodplain [22] (Figure 1).

In a study, [16] expressed the classification of channels and their characteristics as follows Table 1.

The two general indices for analyzing of meanders patterns are 1) sinuosity coefficient 2) central angle. The first part is the ration channel (curvilinear) length and the valley length (straight line). The minimum of this index is zero that shows a straight course. The central angle index is an important index which is studied in meandering of rivers. In a study, [23] using the central angle $(\alpha)$ has suggested a quantitative-based division that it is shown in Table 2. One of the best early study can be mentioned to in a study [23], that rivers have classified according to central angle (Table 2).

The best classification of shapes of river is the Leopold division [22] that the rivers have divided to three types is 1) straight channel 2) meandering channel 3) braided channel.

According to studies of Petts [24], the rivers have been classified to following types (Table 3).

About meandering of rivers have studied more research and writhed many papers. These studies can classify into three sections as 1) studies deal with to
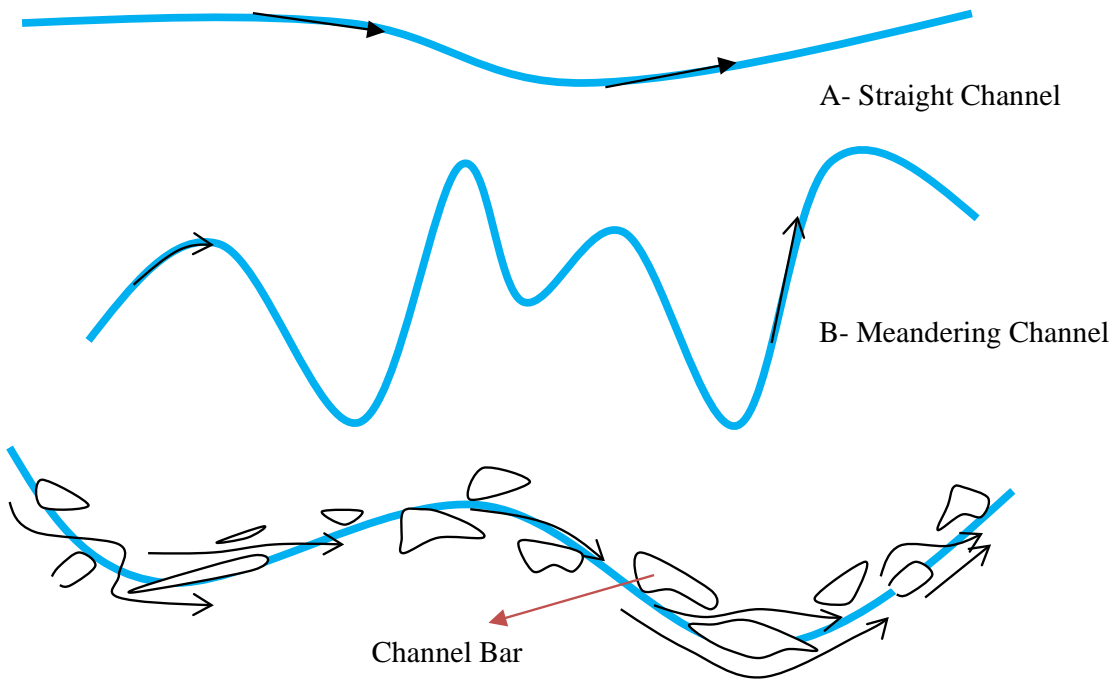

C- Braided Channel

Figure 1. The shapes of a river (A) Straight channel, (B) Meandering channel, (C) Braided channel (Reference: Authors). 
Table 1. Classification of channels and their characteristics [16].

\begin{tabular}{cccc}
\hline Classification of channels & Channels in mountains & & Channels in alluvial plains \\
\cline { 3 - 4 } & & Alluvial fan & Flood plain \\
Riverbed materials & Rock, gravel & Gravelly & Sandy \\
Channel pattern & Strait braided & Braided & Meandering, strait \\
Transportation by running water & Debris flow, traction & Traction & Traction, suspension \\
Depth of channel & various & Shallow & Shallow to deep \\
Gradient of riverbed & Steeper than $1 / 100$ & $1 / 50$ to $1 / 500$ & $1 / 100$ to $1 / 2000$
\end{tabular}

Table 2. The types of alluvial rivers based on central angle ([23] with change (authors)).

\begin{tabular}{cc}
\hline Shape of river & Central angle (deg.) \\
\hline Straight & Undifined or zero \\
Semi Meander & $0<\alpha \leq 41$ \\
Undeveloped meande & $41<\alpha \leq 85$ \\
Developed meander & $85<\alpha \leq 158$ \\
More developed meander like river & $158<\alpha \leq 296$ \\
River ox-bow (serpentine arc) & Up to 296 \\
\hline
\end{tabular}

Table 3. Division of rivers based on sinuosity coefficient [25].

\begin{tabular}{ccccc}
\hline Sinuosity coefficient & $1 \leq S<1.06$ & $1.06 \leq S<1.25$ & $1.25 \leq S<2$ & $2 \leq S$ \\
\hline Type of river & Straight & Sinuous & Meandering & Severe meandering \\
\hline
\end{tabular}

one time period of morphometry of rivers 2) studies deal with to several times period of changing of bottom of river 3) studies deal with to effects of morphology of river into land use. In all of these studies the aerial photograph, satellites images have been using and also the sinuosity and central indices have used.

This lecture is focused on the methodologies of mathematical meandering; more precisely improve the numerical-empirical modeling and deal with to analyzing of two indices as mentioned above and a new index as "flow direction". This index is a new idea that designed with authors. The case study of this paper is Maroon River in Khuzestan province (southwestern Iran). The Maroon River is one of the largest rivers in Zagros Mountain. The approximate area of the Maroon River basin is 4600 square kilometers and length of the Maroon River is about $280 \mathrm{~km}$.

\section{Study Area}

The area of research is located on southwestern of Iran in Zagros Mountains at Khuzestan province. In this research we studied Maroon River that originated in the Zagros Mountain. It forms a large alluvial fan. The start (source) from SadatNil mountains and terminated to Jarahi River. The length of Maroon River is approximately $280 \mathrm{~km}$ and the length of source point to Maroon dam is about 
$150 \mathrm{~km}$ and from Maroon dam to Jarahi River about $130 \mathrm{~km}$ (Figure 2). The Maroon River basin depended on altitude have some different climate. The high land and mountains (up 2500 meters) have cold Mediterranean climate, and hill area have Subtropical (2500 - 1000 meters) and low land and plains have semiarid.

From geomorphology viewpoint, three morphologic faces are dominant on Khuzestan province. At first rocky units which are located in north east of the province. Second; hill units which have coverage in areas located around Dezful, Ramhormoz \& Ahwaz cities. Third, alluvial plains \& flood plains that form the grounds located in south of Ahwaz to Persian gulf beaches \& are a kind of deposited geomorphologies. Mountainous part in Khuzestan is a sample from uniform folded mountainous masses that are named folded Zagros in considering having special lithologic and structural characteristics.

Alluvial coverage has hidden geological characteristics of Arabian plat form but regional data especially geophysical data indicates that in this part of the province, sedimentary sequences have clastic facies and a trend of N-S, as very open folds with sides near to horizon have been folded.

Geological formations of Khuzestan zone has been thrust as a part of folded Zagros have been formed in sedimentary \& tectonic condition hence they have considerable facial differences in terms of time \& space.

Based on their lithological, tectonic \& age of geological formations, rocky out crops of the province can be divided into two tectonostratigraphic units.

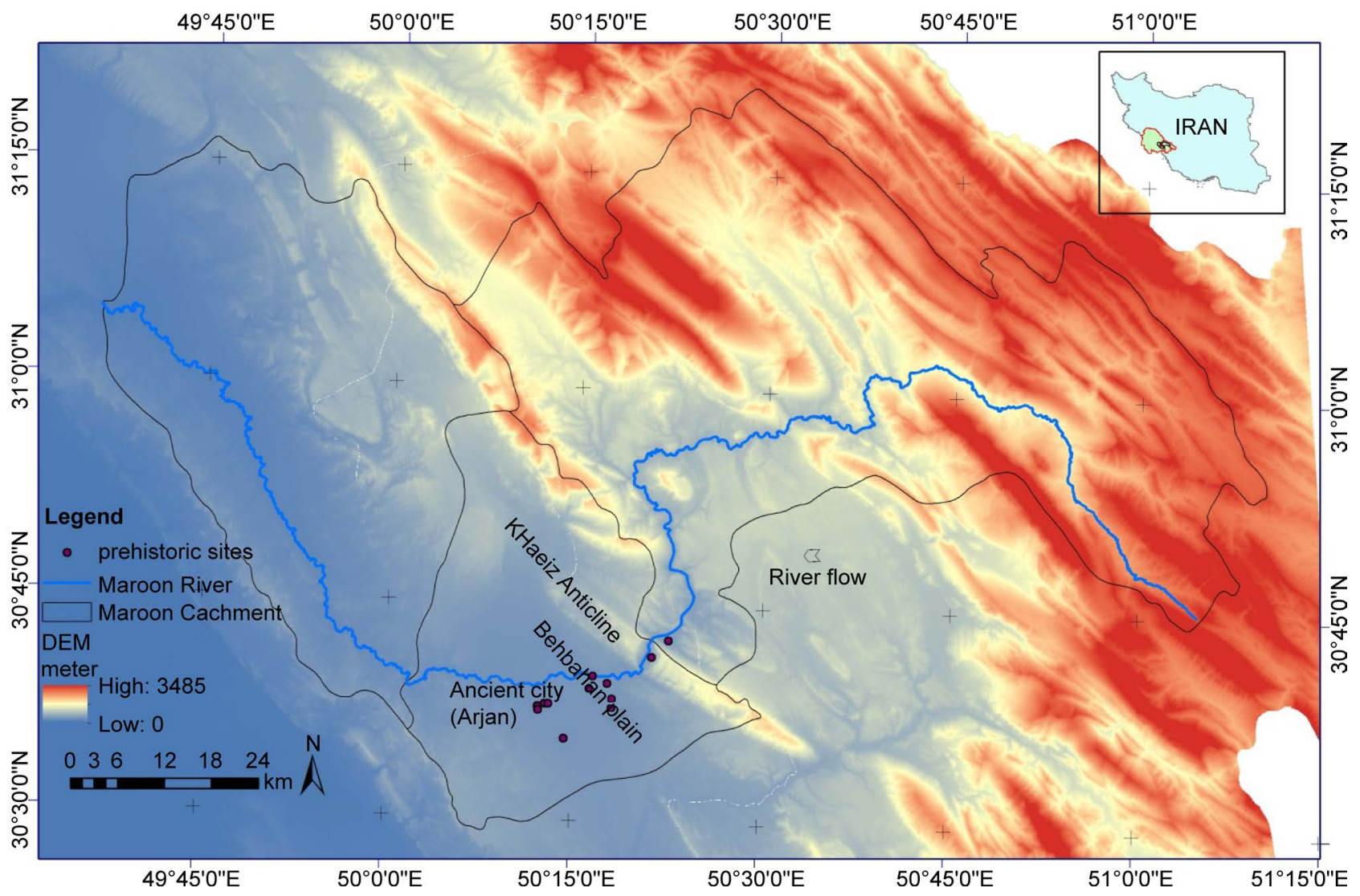

Figure 2. DEM of case study (southwestern Iran, Maroon River). 
1) Marine strata from Jurassic-Iridaceous that have fancies of new Tethys basin. Mentioned strata have out crop generally in core of anticlines in a general trend of NW-SE.

2) Contemporary sequences to alpine orogeny which have Cenozoic age \& its characteristics are representative of deposits in a regressive sea southwards. Mentioned sequence that may be marine and or non-marine \& it contains follow units.

First, Eocene marine strata (Pabedeh Fm.) \& marine limestones of OligoceneMiocene (Asmari Fm.) that it makes reservoir petroleum rock in the province.

Second, clastic-evaporate units of Miocene are known as Fars group formed contemporary to late alpine and regressive marine environments.

Evaporate strata, present in base of this set (Gachsaran Fm.) \& they are cap rock of oil reservoirs of Khuzestan province.

3) Third clastic units after orogeny are well-known to Bakhtiari conglomerate that are representative of relatively vigorous erosions after are alpine orogeny $\&$ finally we should mention from Quaternary clastic deposits that are resulted from weathering in various formations which they have been formed from rock fragments in dimensions of type \& age.

Except to Khuzestan plain that is relatively calm and without earthquake power in mountainous areas of the province, especially in Behbahan vicinity, power of earthquake is high which is sometimes accompanied with damage and ruining [26]. Figure 3 is Geology of region. In this map the geological features of basin of Maroon River was shown.

Pictures following (Figure 4) show a field works of Maroon River and its territory. In this figure the part A is the lake of Maroon dam. The lake is locate in behind of Takab close. The part B is segment of Mogarmoon River in upstream of Behbahan plain. This river is Permanent River. The Part C is Takab close. The direction of this close is north-east. Its length is about $5 \mathrm{~km}$ and the average width about $1.5 \mathrm{~km}$. the Part D is the gates of Maroon dam. The Part E is beginning of reach 5 . After the reach 5 are hills and the topography becomes rougher.

The Maroon River originates from Zagrus high lands and Sadat Mountains. Its catchment is perpendicular to Zagrus ridges and flows toward southwest. The river after passing the high topography and sloped areas with $3100 \mathrm{~m}$ altitudes and joining some subsidiary rivers enters onto Behbahan plain, approximately 350 $m$ in elevation. Then entrance to middle topography regions and joining to Jarahi river and then after some kilometer, entrance to Persian Gulf. Maroon River is a permanent river and its water regime is rainy and snow, that rainy regime is more than snow regime. The catchment of Maroon composed of sediment in Cretaceous period until Paleocene period. These sediments remain of shallow water sea. In the depths of the sea the set of sediments with a very large thickness was deposited that in during the time have been hard and now compose current altitudes.

In this study, the maroon river from source until end (Jarahi River) was divided to 5 reach, first reach from source until Abadeh village with coordinate 


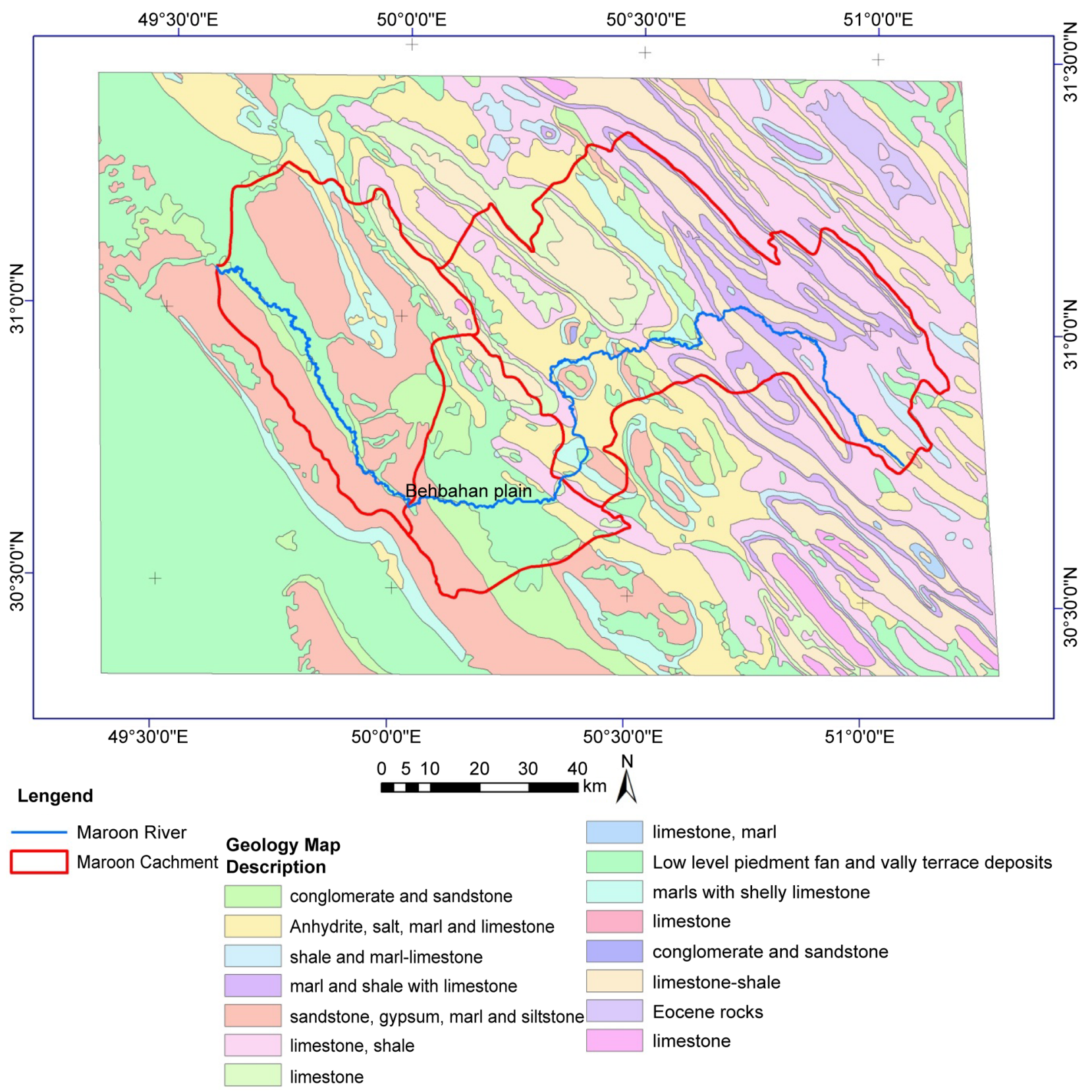

Figure 3. Geology of case study.

$\left(50^{\circ} 54^{\prime \prime} 23^{\prime}, 30^{\circ} 55^{\prime} 32^{\prime \prime}\right)$. The second reach from Abadeh village until Gale Dokhtar with coordinate $50^{\circ} 34^{\prime \prime} 01^{\prime}, 30^{\circ} 58^{\prime} 39^{\prime \prime}$. The third reach beginning end of reach 2 until Maroon dam. The fourth reach is located in Behbahan plain from Maroon dam until Kotak village with coordinate $50^{\circ} 07^{\prime \prime} 32^{\prime}, 30^{\circ} 39^{\prime} 45^{\prime \prime}$ and the fifth reach is the final reach beginning from Kotak village until end (Jarahi River) with coordinate $49^{\circ} 37^{\prime \prime} 18^{\prime}, 31^{\circ} 04^{\prime} 28^{\prime \prime}$ (Figure 5).

\section{Materials and Methods}

In this research, we used of DEM, Topography maps, Arc GIS software, Google earth, field work and library studies. The course of Maroon River accurately extracts from google earth and maps and controlled some part of this course in 


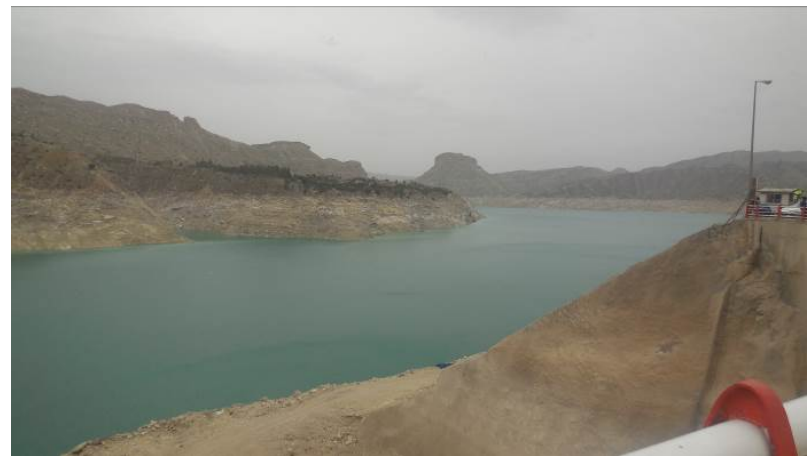

(a)

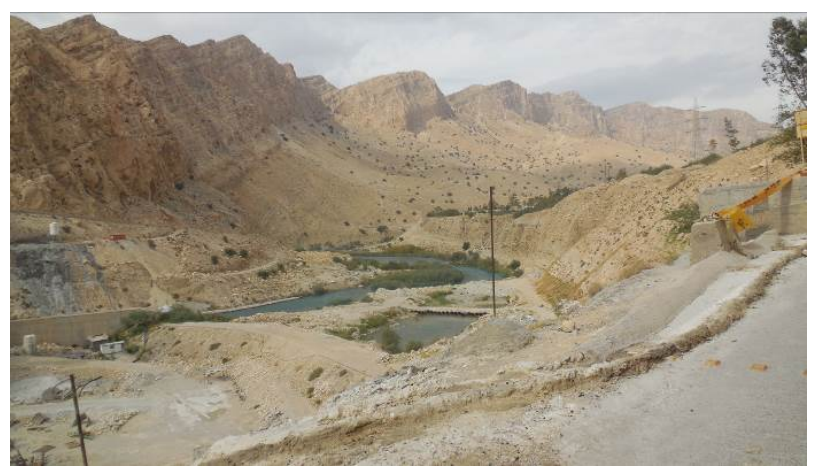

(c)

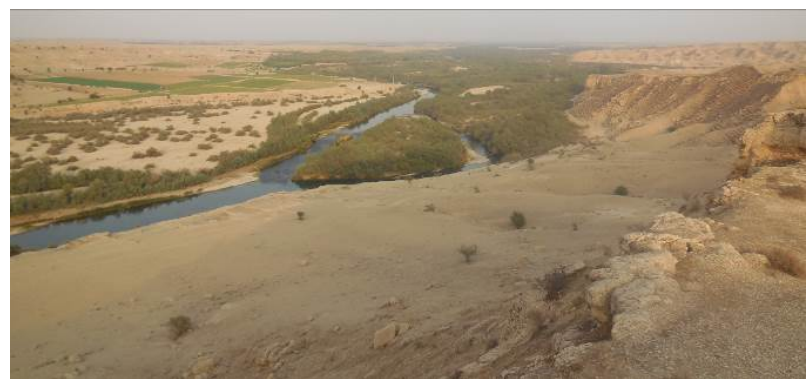

(e)

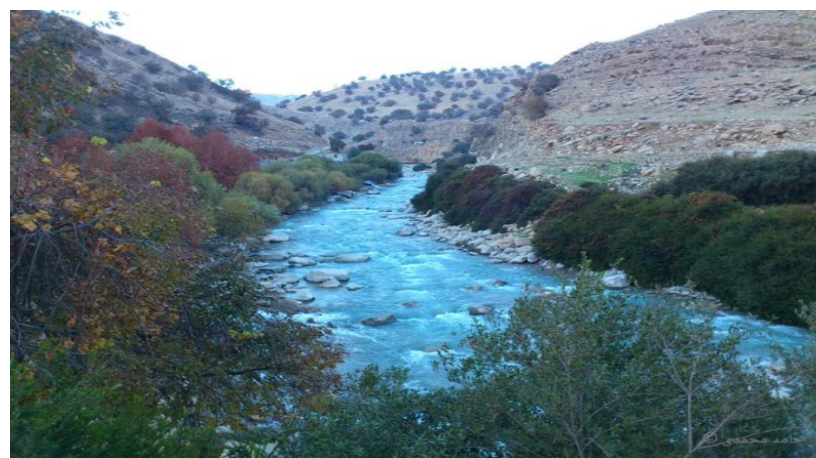

(b)

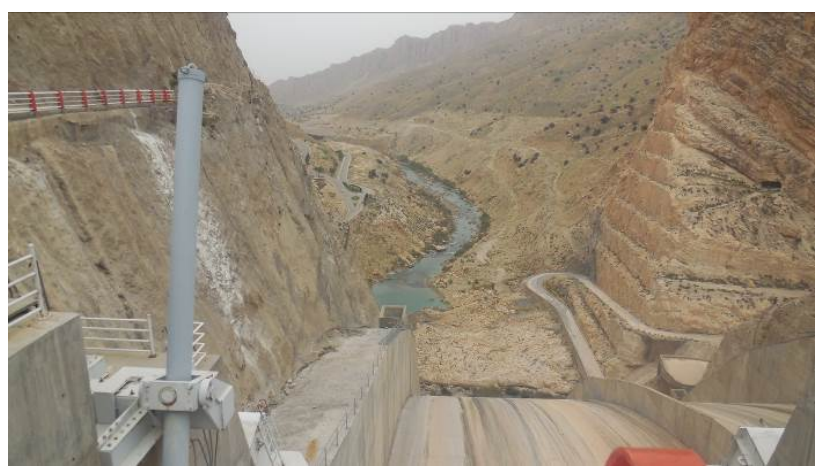

(d)

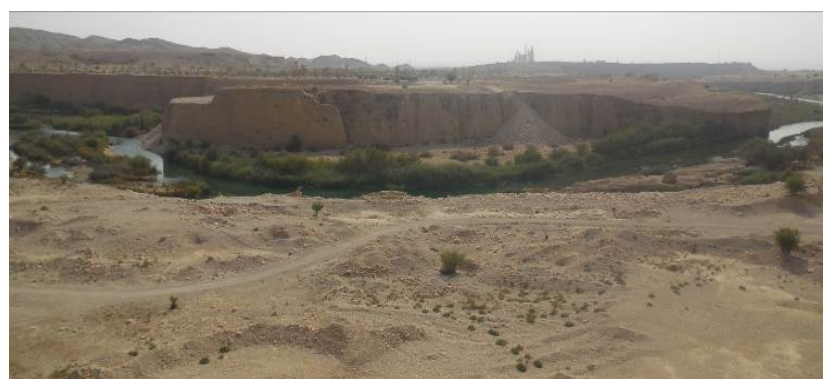

(f)

Figure 4. (a) The lake of Maroon Dam; (b) Mogarmoon River at start of reach 3; (c) Takab close; (d) The gates of Dam and the start of Takab close; (e) Beginning of reach 5; (f) The start point of river in Khaeiz Anticline.

field work. Then the course of river entranced to Arc GIS software, so after that we have a digital course. With using of digital layers identified to meanders of river. We eliminated of some courses of river because of changes in seasons, river discharge and human activities that effecting in the positions of meanders, so we regarded strait lines. In this study we used the total of course from source until end of river, because this idea was simplified relationship between reaches and interpretations. The use of GIS technique in morphometric analysis has emerged as a powerful tool in recent years particularly for remote areas with limited access [27]. In nature rarely don't exit circle's shape meanders with constant radius. Usually in nature the most of meanders are compose arcs that consist of circle arc with different radius. In this study we have assumed that all of meanders were circle with constant Radius $(R)$ and curvature $(\kappa)$. Any line in mathematics has zero curvature $(\kappa=0)$ and extreme radius $(R=\infty)$. In this research forsinuosity and central angle indices we considered any meandering with 
$(R=\infty)$ as strait line. So respectively in sinuosity index the sinuosity coefficient less than 1.06 and in central angle index the angle equal zero. $(\alpha=0)$ The criterion of selected meanders is base of change in the curvature of course of river. So the strait line is without curvature $(\kappa=0)$ and the circular lines have curvature $\left(\kappa=\frac{1}{R}\right)$. This method designed with Authors and its advantage is using of all part of river in calculations of parameters and other advantage is simply identifying the curvature of course and we can control it's with central angle index. In this paper we determined the curvature changes. Then for any curvature fitting the simply circle arc that best matched with meander then all parameters was calculated.

\subsection{Evaluation of Indices}

In this study two index sinousity and central angle for assesment the meandering of Maroon River was calculated. In addition the other index as "flow direction" calculated this index tirst one desighned with authors of paper. The other idea that improves the formulas is mean of central angles in any reach. With awareness of this mean parameter, we will know that meanders are in which time of formation of rover's shape. In follow sections we explained any of these indecis.

\subsubsection{Sinuosity Coefficient (Figure 5 and Figure 6)}

Numerical modeling indicates channel sinuosity will increase along a meandering river until a critical sinuosity of 3.14 (pi) is reached [28]. In following, we described the main definitions:

1) Channel length ( $C$, or arc length): the curve distance between start and finish of any reach.

2) Valley length $(L)$ : the strait distance between start and finish of any reach.

3) Wave length $(\lambda)$ : the distance over which the wave's shape repeats.

4) Inflection point: a point of a curve at which a change in the direction of curvature occurs.

5) Points of curve change $(\times)$ : a point that curve of side of point is different $(+,-$ or 0$)$.

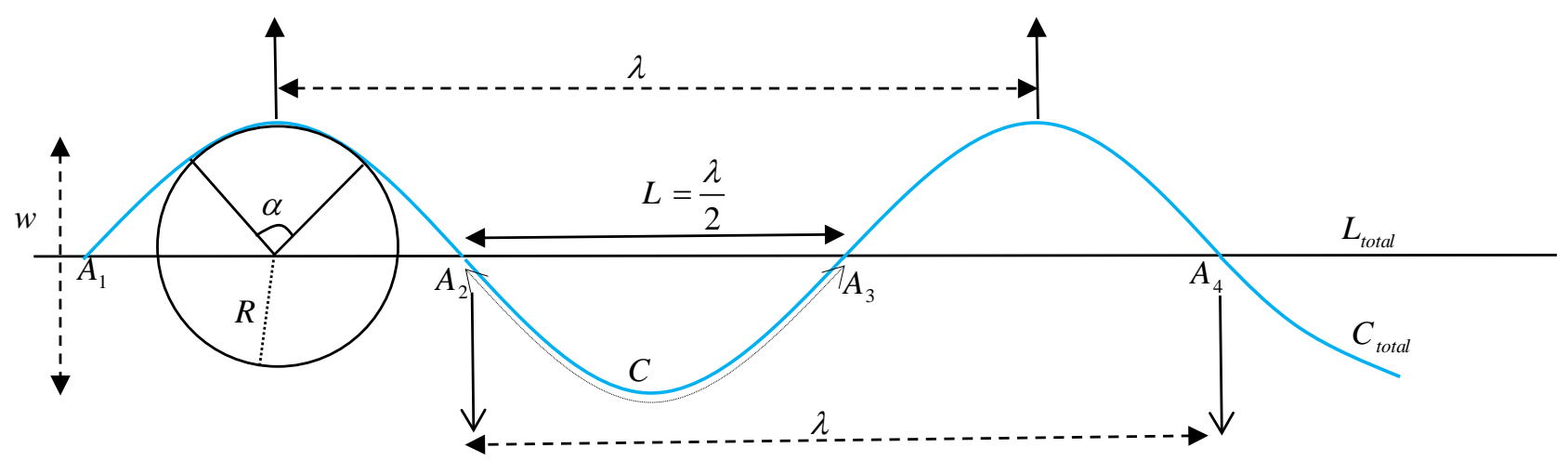

Figure 5. The parameters of a mathematic meander (reference: authors). $w$ : meander width, $R$ : Radius, $\alpha$ : Central Angle, $L$ : valley length, $C$ : arc length, $\lambda$ : wavelength, $L_{\text {total: }}$ total valley length, $C_{\text {total }}$ total arc length. 


\section{Cross symbol:}

Curvature change points

Numbers:

Meanders

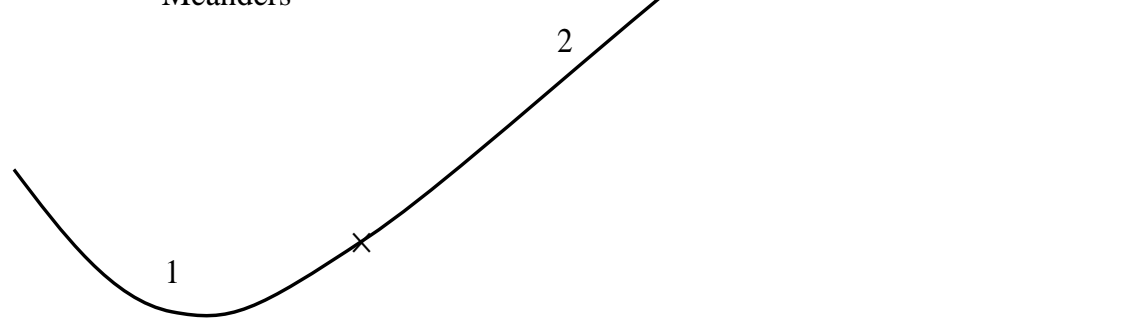

Figure 6. Representation of change curve points, cross symbol $(x)$ the location of curvature change points and numbers are the number of meanders (reference: authors).

6) Sinuosity coefficient: the ration of the curvilinear length (or channel length) and horizontal distance (valley length) between the end points of the river's course.

\subsubsection{Central Angle}

For beginning, we accurately fitted the circles to arcs (meander) of river. This case has doing in Arc GIS software. The perimeter and area of circles has done with using of formulas in software, after this the radius of circles has calculated using follows formula.

$$
\left\{\begin{array}{l}
P=2 \pi R \rightarrow R=\frac{P}{2 \pi} \\
A=\pi R^{2} \rightarrow R=\sqrt{\frac{A}{\pi}}
\end{array}\right.
$$

The valley length all of reach in Arc GIS have drawn. With using of Radius $(R)$ and Valley length $(L)$ parameters can calculated of central angle with following formula.

$$
\begin{aligned}
L^{2} & =R_{1}^{2}+R_{2}^{2}-2 R_{1} R_{2} \cos (\alpha) \stackrel{R_{1}=R_{2}=R}{\longrightarrow} L^{2}=2 R^{2}+-2 R^{2} \cos (\alpha) \\
& =2 R^{2}(1-\cos (\alpha)) \\
& \Rightarrow \cos (\alpha)=1-\frac{L^{2}}{2 R^{2}} \Rightarrow \alpha=\arccos \left(\left(1-\frac{L^{2}}{2 R^{2}}\right)\right)
\end{aligned}
$$

with calculated of $\alpha$ (central angle) and considering of Table 2, the shape of river was achieved.

\subsubsection{Flow Direction Index}

This index for first time presented in this paper and designed with authors. Flow direction index has used according to flow orientation in big area. Until direction of river is not change egregiously the direction consider constant but if the direction of river egregious change to other senses of geographical (like north, northeast, east..., northwest) then the direction of river will change. This index can use for comparing rivers and for their management. 


\section{Results and Discussions}

In this section, the research finding and studies of data analyses have presented.

\subsection{The Reach of River}

In continue, the numbers of reach and meanders have achieved. See the following Table 4 and Figure 7.

The origin of river's water in first reach is produce from raining and melting snows. This reach is located between anticlines. In second reach the Lodab River pouring to Maroon River and increased the discharge of Maroon River. In third reach, the Mogarmoon River jointed to Maroon River, so increased the discharged of Maroon and increased the erosion of river. Fourth reach is located in Behbahan plain. At the beginning of this reach, Maroon dam has made. The Behbahan city is located in this reach and approximately is flat. The fourth reach is located between anticlines and their topography is smoother than first reach. Exceptfourth reach the other reaches are located in areas with topography smooth until hard (mountainous). The Lodab and Mogarmoon Rivers are minor and important

Table 4. The general information of river reaches.

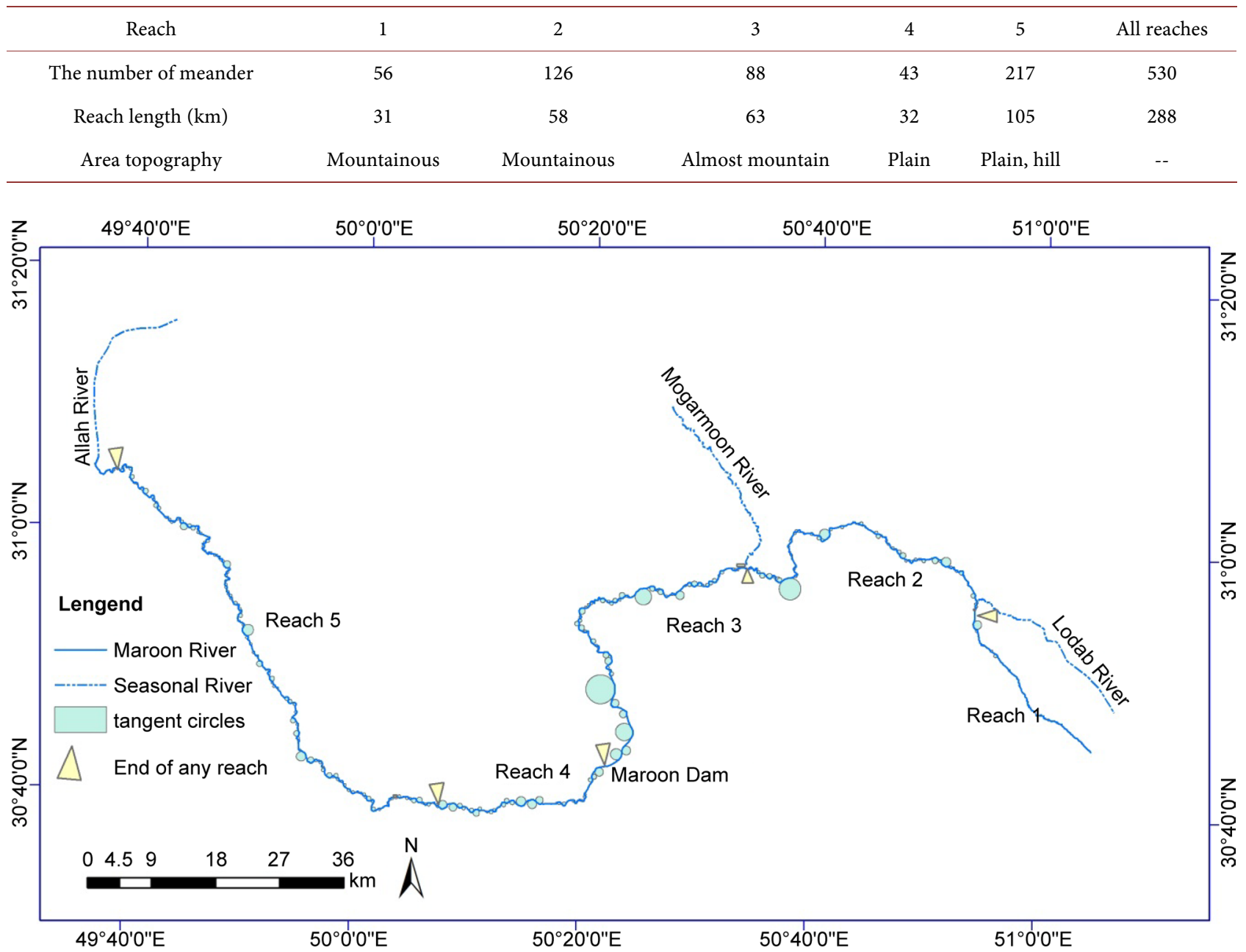

Figure 7. The Range of reach and tangent circles and Seasonal Rivers. 
In this paper, the other seasonal rivers have been regardless.

The first reach:

The number of meanders in this reach cannot be considered fixed because of unstable of course of river and variant raining and human activities. But some of reaches is approximately stable and generated with river erosion and fluvial process. This reach is located between anticlines with $2500 \mathrm{~m}-3000 \mathrm{~m}$ altitude. In this reach in spatial range and time period, Human activities have controlled the morphologic variations of the Maroon River. So the course of first reach isn't stable. The trend of this reach is south-north.

The second reach:

The number of meanders is 91 and its length is $56 \mathrm{~km}$. the course of this reach is approximately stable. The Lodab River is one of the minor river and important, is jointed the Maroon river at start of reach. The Lodab River is getting started form 2200 altitude. After $25 \mathrm{~km}$ from start (reach 2), the trend of Maroon river change its course to west.

The third reach:

The number of meanders is 66 and its length is $63 \mathrm{~km}$. the big change was observed in its direction. The first its direction is toward east-west then toward northsouth. The Mogarmoon River jointed to Maroon River in beginning of reach, so increased its discharged and power of fluvial processes.

The fourth reach:

The number of meanders is 29 and its length is $32 \mathrm{~km}$. the point start of this reach is located in Maroon dam in Takab close. The Takab close is located in Khaeiz anticline. The beginning of this reach exist a deep terrace. After that the River entrance to flood plain and its depth was decreases but increases its width. Because of human activities like materials mining (gravel, sand) the width of river has increased. This reach is located in aquifer and level of ground water near the surface of earth. In this reach exist many aqueduct (Ghanat in Persian) has made in Sasanian Empire, that many of them was dried and useless.

The fifth reach:

This reach is located in Jayezan plain and between anticlines. Its direction of river at beginning is east-west then changed toward north sense. After this the Maroon river in jointed the Jarahi River. This reach approximately located in smooth topography. The width of river in this reach is bigger than the other reaches. The shape of Maroon river depended on season, raining and water gates of Maroon Dam, so changed between strait shape and braided shape in the time. This reach has 150 meanders and its length is $105 \mathrm{~km}$. the shape of some meanders because of human activities and raining time, changed in the time.

\subsection{Sinuosity Coefficient}

In Table 5, the parameters of sinuosity index have presented. According to Table 5, the parameters of Table 4, can be achieved and then these parameters are generated in Table 6. According to Table 6, it can be said the mean of sinuosity coefficient of river was located in sinuous range and all five reach trend to mean- 
der shape. The first and fifth reach have maximum sinuosity mean.

In short distances it would consider the course of river is strait. According to sinuosity coefficient of total (all five reach) in Table 5, it can be said all of the reach (except reach first) are meandering. The first reach is at end sinuous and at the beginning meandering. The second and third reaches are toward intense meandering. The total sinuosity coefficient is the intense meandering. As mentioned above the first reach doesn't have stable meanders so it can be said the course of first reach under different conditions changed.

\subsection{Central Angle (Degree)}

In the following table, for each reach the parameters like minimum and maximum of central angle, mean of reaches and mean radius have been achieved. In second column of Table 7 that added with authors, have showed the some meanders with have central angle is zero or approximately zero. In the other words them sinuosity coefficient less than 1.06 and presented the strait of river. The sum of second

Table 5. The parameters of sinuosity coefissiont of reaches.

\begin{tabular}{|c|c|c|c|c|c|}
\hline parameter & Reach 1 & Reach 2 & Reach 3 & Reach 4 & Reach 5 \\
\hline Numbers of meander & 56 & 126 & 88 & 43 & 217 \\
\hline Wavelength mean & 528 & 449 & 731 & 7224 & 471 \\
\hline Wavelength maximum & 4119 & 1613 & 3581 & 2302 & 1702 \\
\hline Wavelength minimum & 46 & 62 & 125 & 161 & 79 \\
\hline Valley length mean (m) & 468 & 396 & 641 & 640 & 398 \\
\hline Valley length maximum & 3709 & 1477 & 3381 & 2230 & 1580 \\
\hline Valley length minimum & 27 & 51 & 114 & 136 & 64 \\
\hline Sinuosity mean & 1.24 & 1.16 & 1.17 & 1.14 & 1.19 \\
\hline Sinuosity maximum & 1.98 & 1.76 & 1.99 & 1.82 & 2.32 \\
\hline Sinuosity minimum & 1 & 1 & 1 & 1 & 1 \\
\hline Sinuosity less than mean (percent) & 70 & 62 & 37.5 & 60 & 62 \\
\hline Sinuosity less than 1.06 & 19.64 & 35.7 & 34 & 27.9 & 34 \\
\hline Sinuosity between 1.06 and 1.25 & 51.78 & 42.88 & 41 & 58.2 & 37 \\
\hline Sinuosity between 1.25 and 2 & 28.57 & 21.42 & 25 & 13.9 & 28 \\
\hline Sinuosity more than 2 (percent) & 0 & 0 & 0 & 0 & 1 \\
\hline
\end{tabular}

Table 6. Total sinuosity coefficient and type of river (reference: authors).

\begin{tabular}{lcccccc}
\hline \multicolumn{1}{c}{ Reach } & 1 & 2 & 3 & 4 & 5 & All reaches \\
\hline Reach length $(\mathrm{km})$ & 31 & 58 & 63 & 32 & 105 & 288 \\
Valley length $(\mathrm{km})$ & 25 & 33 & 34 & 24 & 68 & 146 \\
Sinuosity coefficient mean & 1.24 & 1.16 & 1.17 & 1.14 & 1.19 & 1.18 \\
Total sinuosity coefficient & 1.24 & 1.76 & 1.85 & 1.33 & 1.54 & 1.97 \\
Type of river & Sinuous & Sinuous & Sinuous & Sinuous & Sinuous & - \\
\hline
\end{tabular}


and third columns is equal with second row of Table 5.

\subsection{The Number of Central Angle in Each Reach}

In Table 8, the numbers of meanders of any reach according to angles classes and mean of angle has presented. In this table the mean parameter for the first time was designed with authors in this paper. The aim of this parameter determined the position of shape of river according to past and future states. According to Table 8, in first reach the Maroon River it is not included the meandering and ox-bow shapes.

In second reach like other reaches, the river it isn't has ox-bow and meandering quasi stats. In this reach river have many undeveloped and developed meandering. According mean of central angle parameter, the river is in early development period.

In third reach, only have two stats like undeveloped and developed meandering, and less than 2 percent is more developed meandering. According mean of

Table 7. The central angle of reaches.

\begin{tabular}{ccccccc}
\hline Reach & $\begin{array}{c}\text { Courses without } \\
\text { curvature (straight) }\end{array}$ & $\begin{array}{c}\text { Number of meanders } \\
\text { (tangent circle) }\end{array}$ & $\begin{array}{c}\text { Minimum } \\
(\text { degree })\end{array}$ & $\begin{array}{c}\text { Maximum } \\
(\text { degree })\end{array}$ & $\begin{array}{c}\text { Mean } \\
(\text { degree })\end{array}$ & $\begin{array}{c}\text { Radius mean } \\
(\mathrm{m})\end{array}$ \\
\hline 1 & 31 & 25 & 64 & 165 & 117 & 98 \\
2 & 35 & 91 & 49 & 170 & 101 & 171 \\
3 & 22 & 66 & 55 & 164 & 99 & 292 \\
4 & 14 & 29 & 48 & 169 & 95 & 306 \\
5 & 67 & 150 & 57 & 173 & 110 & 176 \\
All reaches & 169 & 361 & 48 & 173 & 282 & 201 \\
\hline
\end{tabular}

Table 8. The frequency of central angle and mean of all reaches.

\begin{tabular}{|c|c|c|c|c|c|c|c|c|}
\hline Reach & $\begin{array}{l}\text { Undefined } \\
\text { (zero angle) }\end{array}$ & $\begin{array}{c}\text { Meanders } \\
\text { quantity }\end{array}$ & $\begin{array}{c}\text { Statistical } \\
\text { parameters }\end{array}$ & $0^{\circ}<\alpha \leq 41^{\circ}$ & $41^{\circ}<\alpha \leq 85^{\circ}$ & $85^{\circ}<\alpha \leq 158^{\circ}$ & $158^{\circ}<\alpha \leq 296^{\circ}$ & $296^{\circ}<\alpha$ \\
\hline \multirow{2}{*}{1} & \multirow{2}{*}{31} & \multirow{2}{*}{25} & Percent & 0 & 16 & 68 & 16 & 0 \\
\hline & & & Mean & 0 & 75 & 116 & 163 & 0 \\
\hline \multirow[b]{2}{*}{2} & \multirow[b]{2}{*}{35} & \multirow[b]{2}{*}{91} & Percent & 0 & 34 & 60 & 6 & 0 \\
\hline & & & Mean & 0 & 69 & 113 & 164 & 0 \\
\hline \multirow{2}{*}{3} & \multirow{2}{*}{22} & \multirow{2}{*}{66} & Percent & 0 & 39 & 59 & 2 & 0 \\
\hline & & & Mean & 0 & 70 & 116 & 164 & 0 \\
\hline \multirow[b]{2}{*}{4} & \multirow[b]{2}{*}{14} & \multirow[b]{2}{*}{29} & Percent & 0 & 35 & 62 & 3 & 0 \\
\hline & & & Mean & 0 & 72 & 104 & 169 & 0 \\
\hline \multirow{2}{*}{5} & \multirow{2}{*}{67} & \multirow{2}{*}{150} & Percent & 0 & 25 & 69 & 6 & 0 \\
\hline & & & Mean & 0 & 71 & 119 & 165 & 0 \\
\hline \multirow{2}{*}{ All } & \multirow{2}{*}{169} & \multirow{2}{*}{361} & Percent & 0 & 30 & 65 & 5 & 0 \\
\hline & & & Mean & 0 & 71 & 116 & 165 & 0 \\
\hline
\end{tabular}


central angle, this reach is at early developed meandering, but this reach more developed than second reach.

The fourth reach is located in Behbahan plain. The Maroon dam is located in beginning of reach and Shohada dam is located in middle of reach. These dams and human activities change the morphology of river and with government building the course of river is stable, but in some parts of this reach because of materials mining the width of river has increased. This reach is being undeveloped and developed meandering states.

The fourth reach is located in the hills units (smooth topography). This reach like other reach have two state of shape of river undeveloped and developed meandering, but its development is more than the other reach. This reach has the maximum very developed according to other reach. In this reach some human activities in some parts of river effected to morphology of river.

\subsection{The Flow Direction Index}

According to the following figure, the Maroon River from origin to end (Jarahi River) has 5 big flow directions. This trend has showed in Figure 8. The directions of river flow have showed in Table 9.

\section{Assessment of Errors}

Errors are normally classified in three categories: systematic (or biases), random, and blunders (mistakes).

Blunders are an outright mistake. Systematic errors may be of four kinds: 1. Instrumental, 2. Observational, 3. Environmental, 4. Theoretical.

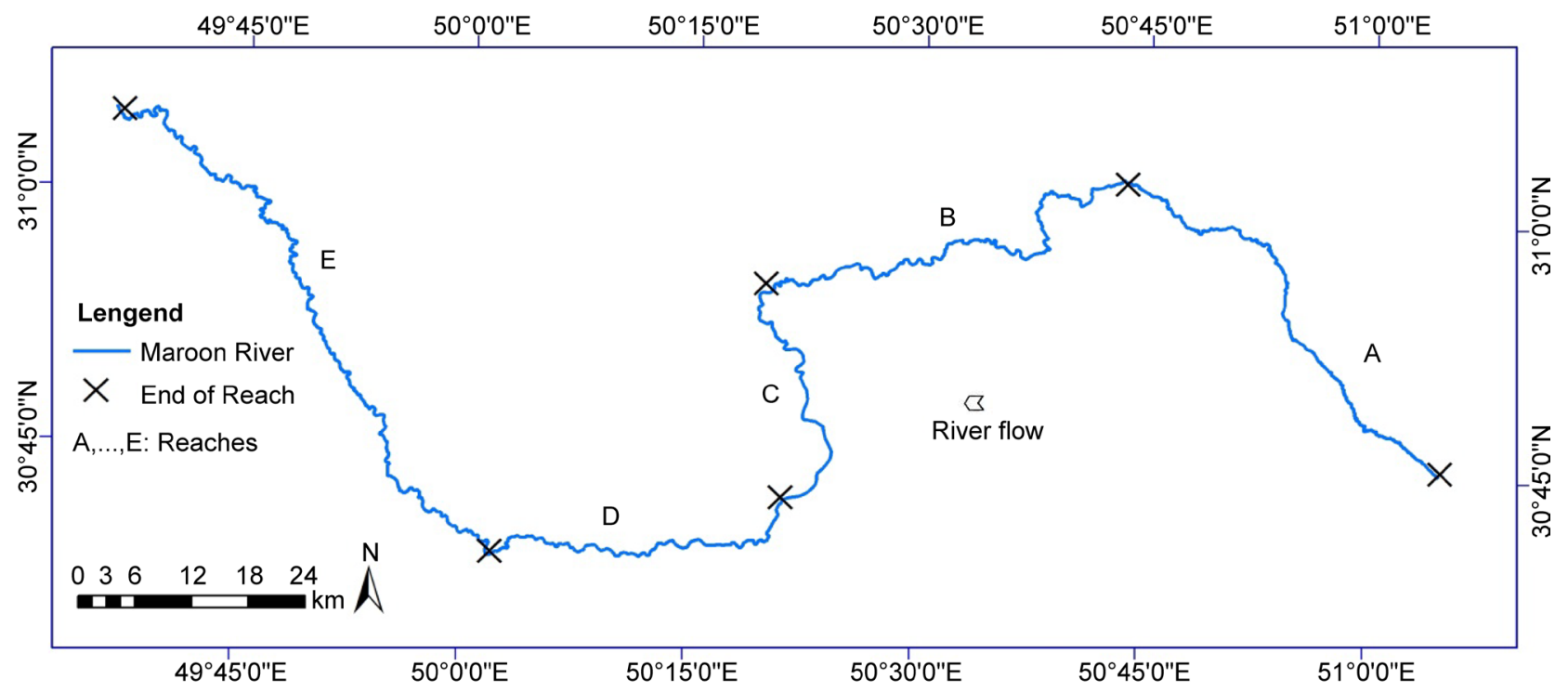

Figure 8. The reaches of flow direction index.

Table 9. River direction index (reference: authors).

\begin{tabular}{ccccc}
\hline Reach & A & B & C & D \\
\hline Direction & Southeast-north West & Northeast-southwest & Northern-southern & Eastern-western \\
\hline
\end{tabular}


And Random Errors included the: 1. Observational, 2. Environmental.

In this research, the errors sources included the following items:

1) Digitating the river.

2) Correct choice of curvature points.

3) Drawing the circles.

4) Calculating the arc length.

For achieve the best results with high accuracy and good precision must using the methods and instruments and data with high resolution [29].

For Example for Sinuosity index it can be said:

$$
\begin{aligned}
& S=(C / L) \\
& \sigma_{S}=f\left(\sigma_{C}, \sigma_{L}\right) \\
& \sigma_{S}=f\left(\sigma_{C}, \sigma_{L}\right)=\sqrt{\left(\frac{\partial S}{\partial C}\right)^{2} \sigma_{C}^{2}+\left(\frac{\partial S}{\partial L}\right)^{2} \sigma_{L}^{2}} .
\end{aligned}
$$

Error Propagation Law

$$
\sigma_{S}=\sqrt{\left(\frac{1}{L}\right)^{2} \sigma_{C}^{2}+\left(\frac{-C}{L^{2}}\right)^{2} \sigma_{L}^{2}}=\frac{1}{L} \sqrt{\sigma_{C}^{2}+\left(\frac{C}{L}\right)^{2} \sigma_{L}^{2}} .
$$

So according to (7) formula, we can said that the errors of sinuosity depended to accuracy of $L$ and $C$. and the accuracy of $L$ is important to accuracy of $C$. because of $\left(\frac{C}{L}\right) \geq 1$.

\section{Effects of Meandering in Settlements}

These effects of meandering on settlements can divide two section, first change river course and second flooding of river. In change course the river remained some paleochannel. In flooding time the river have overflow, in this time the river deposited the parcels with different size. In the beginning, the big size like boulder, rubble, gravel was deposited then fine grained. In around Maroon River there are some villages, cities and prehistoric settlements. Some of these settlements are in downstream of Maroon dam (Figure 9). Using field work and evidences of geomorphology and topography the Maroon River in fourth reach haven't paleochannel in Holocene period. In fourth reach the Maroon River have deep terraces. In flooding times the river water overflow in Behbahan plain and muddy waters have spread on plain. The thickness of muddy layer has been increased over time. At the moment, this thickness is approximately 1.5 to 2 meters. In fourth reach in downstream of Maroon Dam There are a lot of aqueducts (Ghanat in Persian). In depth of Ghanat there are fine and coarse, Rubble and moderate rock. These sediment showed the Maroon River in past had high Energy and could transport these ruble and rock. These Ghanats (aqueduct) was used to transport water to the ancient city of Arjan.

\section{Conclusions}

The sinuosity coefficient and central angle are the main indices for analyzing 


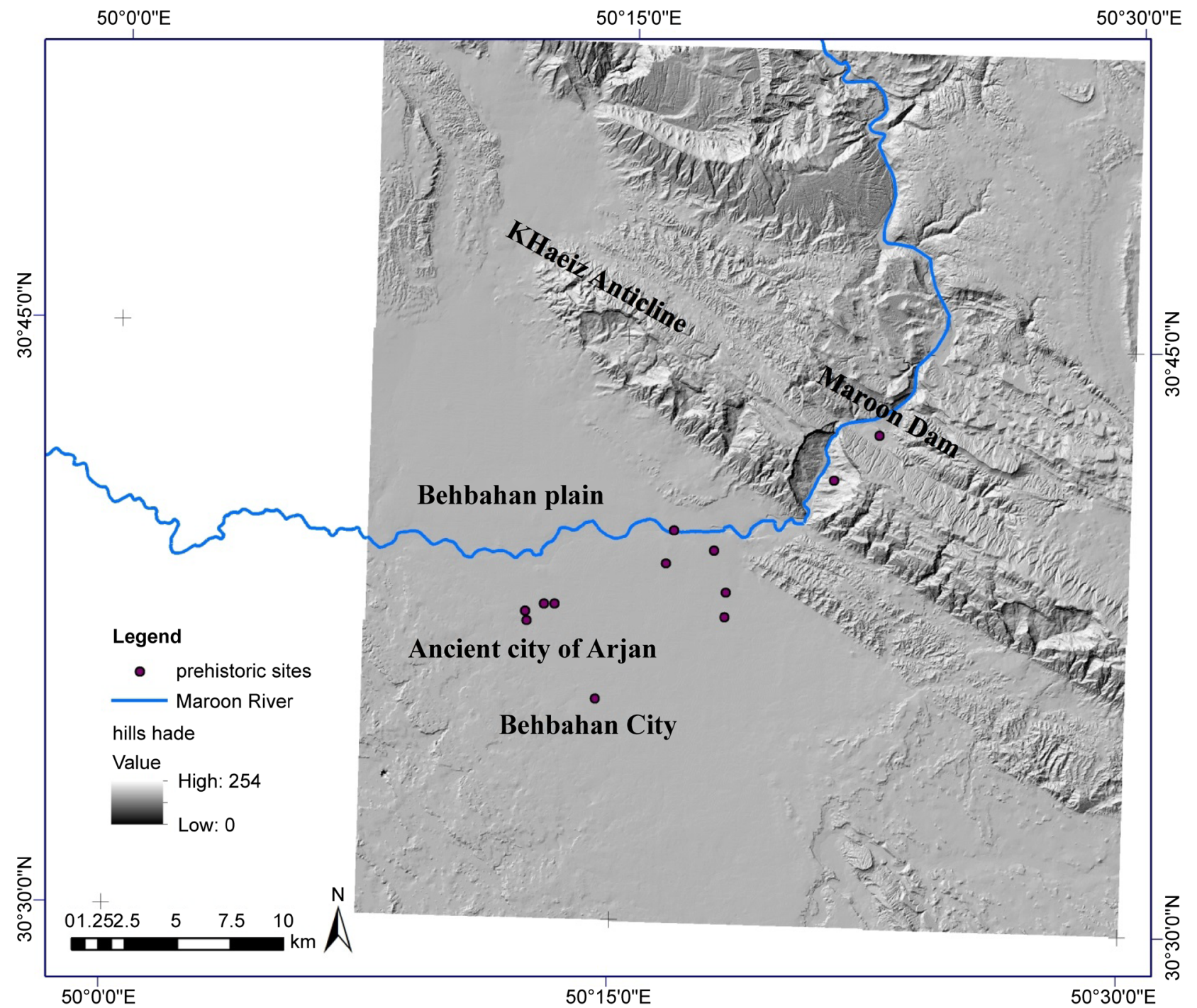

Figure 9. Hill shades and prehistoric sites of downstream of Maroon Dam.

meandering in rivers and the flow direction index can apply in research paper in the future. The Maroon River is an important river in Iran that has more effects on human activity and erosion of their territory. In peripheral of Maroon River particular in Reaches 4 and 5, there are some human settlements that it seems useful to examine the issue from the perspective of geomorphyology. In any reach, the river has all of shapes of river in short distances but in long distances, the shape of river in all reaches is sinuous.

In this research, tectonic and paleo environment and geoarchaeology are not described here. Because the history of human inhabitants in this basin can be traced back to 5000 - until 7000 years before Christ (BC). In order to consider interaction of different factors, the effects of fluvial processes on human prehistoric settlements must be investigated by geomorphology. Bank erosion is the main cause of channel widening and meandering [7]. In general, as a result of human activities, erosion, fluvial process, river discharge, geological setting, mathematical formulas, it can be said the morphometry of river is variable and 
unstable. But in some parts of reaches because of building work from government, the morphology is stable and in areas out of urban region, the above causes exist and make change the morphology.

\section{Acknowledgements}

This article has extracted from a doctoral thesis and has been supported by Iranian Association of Geomorphology and geomorphology group of Tehran University in Iran. The authors appreciate Dr. Abbas Moghadam for his field supported, data and valuable suggestions in the research. Also the authors appreciated of Mahvareh Publication because of its efforts in preparation of books and papers.

\section{References}

[1] Sear, A.D., Newson, D.M. and Thorne, R.C. (2003) Guidebook of Applied Fluvial Geomorphology. R \& D Technical Report FD1914, Publishing Organization Defra, London.

[2] Wolffert, H.P. (2001) Geomorphological Change and river Rehabilitation, Case Studies on Lowland Fluvial Systems in the Netherlands. PhD Thesis, Utrecht University, Utrecht.

[3] Thomas, D.S.G., Ed. (2011) Front Matter. In: Thomas, D.S.G., Ed., Arid Zone Geomorphology: Process, Form and Change in Drylands, 3rd Edition, John Wiley \& Sons Ltd., Chichester.

[4] Tooth, S. and Nanson, G.C. (2011) Distinctiveness and Diversity of Arid Zone River Systems. In: Thomas, D.S.G., Ed., Arid Zone Geomorphology: Process, Form and Change in Drylands, 3rd Edition, John Wiley \& Sons Ltd., Chichester. https://doi.org/10.1002/9780470710777.ch12

[5] Graf, W.L. (1988) Fluvial Processes in Dryland Rivers. Springer-Verlag, Berlin.

[6] Hickin, E.J. (1995) River Geomorphology. Wiley Press, Hoboken.

[7] Wang, S.S.Y. and Wu, W.M. (2004) River Sedimentation and Morphology Modeling. Proceedings of the 9 th International Symposium on River Sedimentation, Yichang, 18-21 October 2004, 71-94.

[8] Charlton, F.G., Brown, P.M. and Benson, R.W. (1978) The Hydraulic Geometry of Some Gravel Rivers in Britain. Report IT 180, Hydraulics Research Station, Wallingford.

[9] Yu, G.A., Disse, M., Tong, L. and Yu, Y. (2015) Evolution of Channel Networks and Morphology of a Dryland River under Human Impacts-A Case from Tarim River in Northwest China. E-Proceedings of the 36th IAHR World Congress, The Hague, 28 June-3 July 2015.

[10] Chang, H.H. (2008) River Morphology and River Channel Changes. Transactions of Tianjin University, 14, 254-262. https://doi.org/10.1007/s12209-008-0045-3

[11] Nongkynrih, J.M. and Husain, Z. (2011) Morphometric Analysis of the Manas River Basin Using Earth Observation Data and Geographical Information System. International Journal of Geomatics and Geosciences, 2, 647-654.

[12] Clarke, J.I. (1966) Morphometry from Maps. In: Dury, G.H., Ed., Essays in Geomorphology, Elsevier Publ. Co., New York, 235-274.

[13] Kanth, T.A. and ul Hassan, Z. (2012) Morphometric Analysis and Prioritization of Watersheds for Soil and Water Resource Management in Wular Catchment Using 
Geo-Spatial Tools. International Journal of Geology, Earth and Environmental Sciences, 2, 30-41.

[14] Garde, R.J. (2005) River Morphology. New Age International (Pvt) Ltd. Publishers, New Delhi.

[15] Mohd, I., Haroon, S. and Bhat, F.A. (2013) Morphometric Analysis of Shaliganga Sub Catchment, Kashmir Valley, India Using Geographical Information System. International Journal of Engineering Trends and Technology, 4, 10-21.

[16] Matsuda, I. (2004) River Morphology and Channel Processes. Fresh Surface Water, $1,1-5$.

[17] Field, J., Tambunan, B. and Floch, P. (2014) Pyanj River Morpholohy and Flood Protection. Publication Stock No. WPS146649, Philippines.

[18] Ibisate, A., Ollero, A. and Diaz, E. (2011) Influence of Catchment Processes on Fluvial Morphology and River Habitats. Limnetica, 30, 169-182.

[19] Georgiou, E. and Sapozhnikov, V. (2001) Scale Invariances in the Morphology and Evolution of Braided Rivers. Mathematical Geology, 33, 273-291. https://doi.org/10.1023/A:1007682005786

[20] Whipple, K. (2004) Alluvial Channels and Their Landforms. In: Surface Processes and Landscape Evolution, 12.163/12.463.

[21] Ritter, D.F., Kochel, R.C. and Miller, J.R. (1995) Process Geomorphology. 3rd Edition, Wm. C. Brown Publishers, Dubuque, IA.

[22] Leopold, L.B. (1994) A View of the River. Harvard University Press, Cambridge.

[23] Kornise, M.R. (1980) Meander Travel in Alluvial Streams. Proceedings of the International Workshop on Alluvial River Problems, Sarita Prakashan Meerut, New Delhi, India, 35-82.

[24] Petts, G.E., et al. (1986) Historical Change Alluvial River. John Wiley and Sons, Hoboken.

[25] Leopold, L.C., Wolman, M.G. and Miller, J.P. (1970) Fluid Process in Geomorphology. Freeman Publishers, San Francisco, 522.

[26] Geological Survey \& Mineral Exploration of Iran. www.gsi.ir

[27] Withanage, N.S., Dayawansa, N.D.K. and De Silva, R.P. (2014) Morphometric Analysis of the Gal Oya River Basin Using Spatial Data Derived from GIS. Tropical Agricultural Research, 26, 175-188.

[28] Stolum, H.H. (1996) River Meandering as a Self-Organization Process. Science, 271, 1710-1713. https://doi.org/10.1126/science.271.5256.1710

[29] Ranjbar, A. and Hajizadeh, A.H. (2016) Theory of Errors. 2nd Edition, Mahvareh Press, Tehran. (In Persian) 